\title{
Translanguaging as a Pedagogical Strategy in EFL Classroom
}

\author{
Rahmawansyah \\ IAIN Fattahul Muluk Papua \\ rahmawansyah@iainpapua.ac.id
}

\begin{abstract}
This study investigated the practice of Translanguaging in EFLClassroom. It focused to explore the reason of teacher for using translanguaging in EFL Classroom, and explored the benefits from the teacher's translanguaging on students in EFL Classroom. This study applied qualitative method, the instruments were interview and recording. The result of interviews and recording transcribed and analyzed based on the reason of the teacher for using translanguaging in EFL Classroom, and the benefits of teacher's translanguaging on students. The findings was the teacher and students used three kinds of languages in practice of translanguaging during teaching and leaming process in EFL Classroom namely; the foreign language is English, the Indonesia language, and the local language is Konjo. Therefore, translanguaging always used by teachers in teaching and leaming process because teachers have many reasons : translanguaging used by the teachercould help the students to be a more active in teaching-leaming process, translanguaging used by the teacher could to create the effective communication between teacher and students in classroom, translanguaging used by the teacher to help the low students in English vocabulary, translanguaging used by the teacher to accommodate local language in EFL classroom. There were significant benefits of translanguaging used by the teacher in classroom interaction. Thus, the teacher's translanguaging inEFLclassroom made the students more active in leaming, interested in learning and acquiring the knowledge easily, easy to speak up, created the fun learning and enjoy the classroom, add the students' vocabulary, and interact well to their teacher..
\end{abstract}

Keywords: translanguaging, pedagogical strategy, EFL Classroom 


\section{INTRODUCTION}

An English teacher can use translanguaging as one of communication strategies in classroom. Translanguaging not only can utilize to assist the process of English teaching as foreign language but also translanguaging involve the use of students' home language in learning English. It can interest students to learn English. The effective communication connection between teachers and students will harmony by translanguaging. So, translanguaging has applied by many English teachers as pedagogic strategies in process of English teaching as foreign language. The function of translanguaging not only as pedagogic strategy for the teacher in classroom, but also Translanguaging has applied in out of classroom. Such, in south Sulawesi is one of province in Indonesia with many kinds of local languages. For instance, In South Sulawesi has Bulukumba regency with Buginese and Konjo language as local language, Indonesia as national language, and English as foreign language. Most Indonesian becomes bilingual and multilingual, because Indonesia has local language, national, and foreign languages. In fact, many Indonesians are capable to translanguaging their languages.

In academic context, " There are some researches about translanguaging that focused on the impact of translanguaging strategies use on bilingual leamers, and the students' attitude towards the uses of translanguaging in English language classroom, and reflecting on translanguaging in multilingual classrooms" But few studies concentrated in teacher's translanguaging in EFL especially about the teacher's reasons for using translanguaging in EFL classroom and the benefits of teacher's translanguaging on students in EFL Classroom. There were some of English teachers when they were teaching in the classroom they taught in full $\mathrm{L} 2$ and sometimes change to Indonesia as national language. However, one of the cases faced in the classroom is unsupported circumstances. Sometimes, there are some teachers or lecturers who force the use of L2 to teach L2 that instead of making the students master the L2. This way of teaching can makes the students confuse.

Because it's language is not their daily language in their daily life. Some students got difficulty in using English. They will chose to keep silent than speak up during learning and teaching process. So, the main task for the teacher to understand how to make the students interested to material and how to make students able to show their skills in leaming process. The students and the teachers can use many strategies; one of them is using translanguaging in classroom. Where students are allowed to write and speak with their home language and then translanguaging to $\mathrm{L}$ 2. Translanguaging is the way of using the $\mathrm{L} 1$ of the students to help the student learning the L2 in the classroom. Translanguaging will optimize the student's mastery in L2 since the process of teaching and learning is effective.

The students usually used translanguaging unconsciously. This means that the students are not aware of the function and outcomes of the translanguaging process. Therefore, in some cases it may be regarded as an automatic and unconscious behavior. Tang (2002) says that using translanguaging in teaching is not considered as a sign of defect in the teacher or students. Instead, it is a careful strategy used by the teacher or students and is allowed whenever necessary with some learners' specific situations. Teachers use translanguaging as a mean of providing students with the opportunities to communicate and improve student's understanding and students may use translanguaging as helper to make clear their opinion that they explain to teacher in classroom interaction. Translanguaging helps to facilitate the flow of classroom interaction between students and their teacher since the teachers do not have to spend too much time trying to explain to the students or searching for the simplest word to clarify any confusion that might arise during the teaching process.

Based on the explanation above, the researcher is interested in investigate the translanguaging in $\mathrm{EFL}$ 
classroom context of SMAN. 11Bulukumba. Hence, the researcher was focused on the grand theory that use here is Garcia (2014:3) which states that the Translanguaging is not utilize to differentiate between two languages or the shift of the languages but it is used to mediate each other. Therefore, the researcher interested to examine the use of translanguaging as pedagogical strategy by the teacher in EFL classroom. It focuses on the teacher's reason for using translanguaging, and the benefits of teacher's translanguaging to students in EFL classroom.

\section{METHOD}

This study applied a descriptive qualitative method to describe and analyze the use of translanguaging as pedagogical strategy by the teacher in EFL classroom. The data analyzed was taken in form of utterances and words produced by the teacher and students in teaching and leaming process in XI IPA1 grade of SMAN 11 Bulukumba.

The participants of this research are one teacher and ten students of XI IPA grade SMAN 11 Bulukumba. In obtaining the data, the researcher used audio recordings to record the process of classroom observation during two meetings and the process of interview teacher and some students. The researcher also used an interview guide as an instrument for getting information such as the reason of the teachers for using translanguaging and the teacher's translanguaging benefits.

Overall, there were thirteen recordings taken for this study which include two recordings of classroom observation and eleven recordings of participants' interview. The process of data analysis based on Braun and Clarke (2006) who proposes six guidelines of analysis activities. They are (1) familiarizing yourself with the data, (2) generating initial codes, (3) the researcher read throughout each transcript to immerse in the data, (4) reviewing themes, (5) defining and naming themes, and (6) producing the report. Initially, based on the purposes of this reserach, the data transcribed and selected. Then, in the forms of extracts, the data interpreted and analyzed. In the extracts, the relevant data identified and discussed.

\section{FINDINGS AND DISCUSSION}

Findings of this research focus three main points: the reason of teachers for using translanguaging, and the benefits of teacher's translanguaging toward students in EFL classroom.

\section{The teacher's reason for using Translanguaging in EFL Classroom.}

a. To helping the students take a more active

$R$ : Was the use of translanguaging productive during yourlesson?

DT: It is productive, Because of it made the students more active in classroom

Based on the extract above, it indicates that the teacher gave opinion about the use of translanguaging. She said that, "the use of translanguaging is too productive, because translanguaging made the students more active in classroom. The translanguaging should be used because it can help their students take more active in teaching leaming process. In addition, when the teacher used translanguaging, the teacher believes that translanguaging can really help students to understand the subject content because sometimes there are certain words or terms students are not familiar with but when explained in their mother tongue they understand well. That's way made the students more active during lessons.

b. Tocreate the effective communication.

$R:$ Were there times when you as a teacher used your mother or local languages during your lesson?

$D$ :I used my local language or my mother tongue when $i$ was explaining the material in English. But my students still look confuses or no understood. So to create the well communication between my students and me. And also the learning objectives can be achieved. Idecided to use translanguaging.

From the extract above it indicates that, created a well communication is belonging the reason of the teacher used translanguaging in classroom. In translanguaging, the used of local language or mother 
tongue and English as subject language are needed. Because when the teacher's explanation in full English made students confuse. It is very important for the teacher to be aware how to create a well situation. One of strategy that can use by the teacher is do translanguaging.

c. The lack of vocabulary

$R$ : In your opinion, should the use of two or more languages be allowed in lessons? Explain please!

DT: Yes, I was allowing my students to used two or more language during lessons. Because as $i$ know one of the problem that faced by my students in SMAN 11 Bulukumba is the lack of vocabulary in English. So, the used of local or national languages and English in the same time is one of way to help continue their communication in English classroom. They have konjo as local language, Indonesia as national language. So it made them capable to usedtranslanguaging.

Based on the extract above indicates that, the students' problem is the lack of vocabulary made the teacher should be used translanguaging in teaching process. The teacher said that, because as $i$ know one of the problems that faced by my students in SMAN 11 Bulukumba is the lack of vocabulary in English. So, the used of local or national languages and English in the same time is one of way to help continue their communication in English classroom. From the utterance, the teacher was aware the important of translanguaging to use in the teaching and learning process. It can help the teacher to keep the well interaction between teacher and her students. Because the lack of vocabulary from the students. It becomes obstacle to give response to their teacher in teaching process. So, through using translanguaging made the teacher and students still communicate in classroom.

d. As need to accommodate local language

$R \quad:$ What could be the reasons why the English teacher usually used translanguaging in lessons? Give your Opinions

DT: I appreciate the use of Full English, but there is a need to accommodate local languages in my lessons because local languages may help students to understand the subject content better. So, I am sure the results will also improve.

Based on the extract above shows that, the teacher agree with the used of full English language in classroom. But as teacher, she also should aware to the students' weakness. English is not daily language for them. They sometimes feel confuse with their teacher's explanation. So, the teacher needs to consider the use of translanguaging with accommodate their local language in teaching and learning process. She said that, 'I appreciate the use of Full English, but there is a need to accommodate local languages in my lessons because local languages may help students to understand the subject content better. So, I am sure the results will also improve. She feels if local languages were accommodated in lessons, it would certainly help students to understand the subjects better. The teacher has also indicated that if one of the common local languages in each region were allowed to be used concurrently with the official language; it could assist students to understand better.

\section{The benefits of teacher's Translanguaging on studentsin EFL Classroom.}

a. Students are more active

$R:$ Is there any effects of teacher's translanguaging toward students' learning process in ELT? Please give explanation!

RH: Yes it is, karena saya suka jika guru[because I like if my teacher] combinebetween English and Indonesia language andI become more active in learning process. Kebanyakan siswa tidak memahami kalau guru memakai bahasa inggris terus.[some of students did not understand if teacher used full English]

From the extract above shows that she was interested if her teacher used Translanguaging in teaching and leaming process. It made the students more active in their leaming. In addition, if the teacher used full English in teaching process, it made the situation of the class become ineffective and the students feels bored. 
b. Students are interested in leaming and acquiring the knowledge easily.

$R:$ Is there any effects of teacher's translanguaging toward students' learning process in ELT? Please give explanation!

HP : Yes it is, the teacher's translanguaging has big effect for our learning. Because I easier to understand the material. And i like my teacher, she able to teach English very well with translanguaging.

From the extract above indicates that the student was interested with her teacher's competent in teaching English. She interested to studying if her teacher used Translanguaging in learning process. In this case, the student said that, Translanguaging has big effect for her leaming. Because of Translanguaging made her to understand quickly.

c. Students are easy to speak up

$R:$ Is there any effects of teacher's translanguaging toward students' learning process in ELT? Please give explanation!

A :Yes, because translanguaging can help us to speak up in English learning

From the extract above shows that she was interested to the learning process if the teacher used translanguaging. Translanguaging made the student to speak up than silent during lessons. Because, it was allow the students to use their native language as positive linguistic resource.

d. Students enjoy the EFL classroom.

$R \quad$ : Do you think that students will be interested in leaming if your teacher uses translanguaging when teaching, why?

MH: Students will be interested because students will quickly understand and spontaneously we will laugh when the teacher uses translanguaging which is also the students more spirit because not burdened with full English.

Based on the extract above shows, the student was interested to studying English if her teacher used translanguaging. Because she understands quickly and spontaneously give humor for their classroom situation. Through the situation, the student was enjoyed to studying with translanguaging method. In addition, the student also more spirit without burden with full English.

e. Students can add their vocabulary.

$R \quad$ : Is translanguaging one of the best ways of learning in EFL classroom? Why? If yes, Please explain your reason!

$R H$ : Yes it is.It is good way for many students with lack vocabulary in English

From the extract above shows that, the teacher's translanguaging gave positive effect for the learning of student. The student likes to study with translanguaging used by the teacher. Because the student still can understand the teacher's explanation with the lack vocabulary. Besides that, the student also can add her vocabulary through the teacher's explanation. So, when the teacher used translanguaging, the student will try to know meaning of the new word that said by the teacher. Automatically, it can help to add the student's vocabulary.

f. Students interact well to their teacher

$R$ :Does using translanguaging during teaching

and leaming process make the classroom

effectively?

EA : Effective, because students receive lessons calmly and interact well when teachers ask questions and we answer

From the extract above shows that, if his teacher used translanguaging in teaching process, it made the student more interact well to their teacher. Furthermore, if the student study, sometimes, he are nervous and he afraid to ask his teacher and answer the teacher's question. Through teacher's translanguaging in the classroom can make the communication more open between students and teacher because the students are not afraid with their teacher

\section{DISCUSSION}

From the data gained through the recording of classroom observation and interview with one teacher and 10 students, it could be concluded that the teacher and the students agreed that the use of translanguaging in teaching and learning process. This is similar with 
statement of Martin (2006) stated that translanguaging 'the use of local languages alongside the 'official language' of the lesson. And also according to Cook (2001) referred that translanguaging in the classroom as a natural response in a bilingual situation. Beside that translanguaging always used by the teachers in teaching and leaming process because the teachers have many reasons namely: translanguaging used by the teacher could help the students to be a more active in teaching-learning process, translanguaging used by the teacher could to create the effective communication between teacher and students in classroom, translanguaging used by the teacher could to helping the low students in English vocabulary, translanguaging used by the teacher could to accommodate local language in EFL classroom. So, through the teacher's translanguaging in EFL classroom made the students more active in learning, interested in learning and acquiring the knowledge easily, easy to speak up, created the fun learning and enjoy the classroom, add the students' vocabulary, and interact well to their teacher.

Translanguaging as pedagogical strategy was used by the teacher has big benefits for the students' understanding in teaching and learning process. It can help the students easier to receive the material from the teacher. For instance, the students in SMAN 11 Bulukumba have Indonesia language and Konjo language was gave positive effects in learning English as foreign language. However, there is another term from translanguaging that known as code switching. Even though, it similar by action that can also use in classroom interaction by many teachers and students in teaching and learning process. And they were different by function. The last, translanguaging was very suitable as strategy for the teachers and students used in teaching and learning process. It supported by Garcia (2012:2) defines translanguaging as "the discourse practices of the bilinguals, as well as pedagogical strategies that use the entire linguistic repertoire of bilingual students flexibly in order to teach both rigorous content and language for academic use. And translanguaging can also help students by projecting a safe environment where their identities and cultures are valued, which helps the more reserved students take a more active and involved role in their education (Martin,2005).

\section{CONCLUSION}

Translanguaging in EFL classroom of SMAN 11 Bulukumba occumed between teachers to students and students to other students in teaching and learning process. Translanguaging as strategy was very important for the teacher and students during teaching and leaming process. The teacher has considered translanguaging as a need for flexibility in language usage in classroom.

translanguaging always used by the teachers in teaching and leaming process because the teachers have many reasons namely: translanguaging used by the teacher could help the students to be a more active in teaching-learning process, translanguaging used by the teacher could to create the effective communication between teacher and students in classroom, translanguaging used by the teacher could to helping the low students in English vocabulary, translanguaging used by the teacher could to accommodate local language in EFL classroom. There were significant benefits of translanguaging used by the teacher in classroom interaction. So, through the teacher's translanguaging in EFL classroom made the students more active in leaming, interested in learning and acquiring the knowledge easily, easy to speak up, created the fun learning and enjoy the classroom, add the students' vocabulary, and interact well to their teacher.

As a strategy, translanguaging were considered to be helpful and useful. Not only to create good communication, but also to build safe environment in the EFL classroom. In order to make the students are enjoyable and prefer to speak up in the teachinglearning process. Therefore, in researcher's opinion translanguaging is a need for flexibility in language usage in the classroom to enhance interaction, learning, 
and the participation of students, because their lack of competence in English causes them to be quiet, passive, unmotivated, and less confident. For further research, the study of translanguaging can be extended by conducting the research in order different content and setting, because in many studies about translanguaging always investigated translanguaging in educational setting, especially in classroom context. Furthermore; the researcher recommends observing about translanguaging in out of the classroom.

\section{REFERENCES}

Braun, V. \& Clarke, V. (2006). Using thematic analysis in psychology. Qualitative research in Psychology, 3,77-101.

Cook, V.J. (2001). Using the first language in the classroom. Canadian Modern Language Review, 57,402-423.

García, Ofelia, Skutnabb-Kangas, Tove, \& TomesGuzmán, Maria E.(2006). Imagining multilingual schools: Languages in education and glocalization: Multilingual Matters Clevedon, UK.

García, O. (2009). Bilingual education in the 21st century: A global perspective. Malden, MA and Oxford: Blackwell/Wiley.

García, O. (2009b). Reimagining Bilinguals in Education for the $21^{\ddagger}$ Century', NALDIC (National Association for Language Development in the Curriculum), $17^{\text {th }}$ Annual Conference: Integrated language, IntegratedCurriculum ,http://www.youtube.com/watch?v=rVI4 $\underline{1 \mathrm{CMw} 6 \mathrm{HM}}$

García,O.(2011a)'Educating NewYork's bilingual children: Constructing a future from the past' International Journal of Bilingual Education and Bilingualism 14:2,133-153.

García,O.(withMakar,C.,Starcevic,M.andTerry,A.)(2 011c) $)^{6} \quad$ Translanguaging of Latino Kindergarteners' in $\mathrm{K}$. Potowskiand $\mathrm{J}$. Rothman(eds) BilingualYouth: Spanish in English Speaking Societies (Amsterdam: JohnBenjamins), pp.33-55.

García, O., Flores, N., \& Chu, H.(2011). Extending bilingualism in US secondary Education: New varations. Intemational Multilingual ResearchJournal, 5(1), 1-18.

García, O., \& Sylvan, C. (2011). Pedagogies and practices in multilingual classrooms: Singularities and pluralities. The Modem Language Journal, 95, iii.

García, O. (2012). Theorizing translanguaging for educators.In C. Celic\& K.Seltzer, Translanguaging: A CUNY-NYSIEB guide for educators (pp. 1-6). New York, NY: CUNY-NYSIEB.

García,O.andKleifgen,J.(2010) Educating Emergent Bilinguals. Policies, Programs and Practices for English Language Learners (NewYork: Teachers College Press).

García, O. \&Leiva, C. (2014).Theorizing and Enacting Translanguaging for Social Justice. In A. Blackledge\& A. Creese (Eds.), Heteroglossia as Practice and Pedagogy (pp. 199-216). New York: Springer.

Garcia, O. \& Wei, L (2014). Translanguaging: Language, Bilingualism and Education: Palgrave Pivot and Mac Milan.

García,Oand Sylvan,C.(2011) 'Pedagogies and practices in multilingual classrooms: Singularities in uralities', Modern Language Journal,95(iii),385-400

Mahmud, M. (2017).Doing Discourse Analysis An Introduction. Yogyakarta: Phoenix Publisher

Martin, P.(2005)“'Safe'Language Practices in Two Rural Schools in Malaysia: Tensions between Policyand Practice 'in A.M.Y 
.Linand P.W. Martin (eds) Decolonisation ,Globalisation. Language- in- Education Policyand Practice (Clevedon, UK: Multilingual Matters),pp.74-974.

Martin, P. (2005). Bilingual encounters in the classroom. In Dewaele, J.M. \& Housen, A. (Eds.) Bilingualism: Beyond basic principles. p. 67-87. Clevedon, UK: Multilingual Matters.

Martin, Peter. (2006). Accomplishing Lessons in Postcolonial Classrooms: Comparative Perspectives from Botswana and Brunei Darussalam. Comparative Education, article.

Oxford Advanced Learner Dictionary $\left(7^{\text {th }}\right.$ Ed). 2005. Oxford University Press.

Program Pascasarjana UNM. (2010). Pedoman Penulisan Tesis dan Disertasi. Makassar: Badan Penerbit UNM. 